\title{
The influence of chloride and sulphate ions on the slaking rate of lime derived from different limestone deposits in South Africa
}

\author{
O Gheevarhese ${ }^{1}$, CA Strydom ${ }^{1 *}$, JH Potgieter ${ }^{2}$ and SS Potgieter ${ }^{3}$ \\ 1 Department of Chemistry, University of Pretoria, Pretoria, 0002 \\ 2 Department of Chemical \& Metallurgical Engineering, Technikon Pretoria, Private Bag X680, Pretoria, 0001 \\ ${ }^{3}$ Department of Chemistry and Physics, Technikon Pretoria, Private Bag X680, Pretoria, 0001
}

\begin{abstract}
This paper describes an investigation into the influence of chloride and sulphate ions on the slaking of lime prepared from limestones of different geological origin in South Africa. It was endeavoured to assess the effects of the presence of chloride and sulphate ions on the hydration rate of lime, compared to its slaking in pure water. It was found that the rate of hydration is slightly retarded in the presence of a high concentration of chloride ions, while sulphate ions retard the slaking of lime significantly. This investigation indicated that impurities present in the original limestone, as well as those commonly found in water used for slaking purposes, may exert an influence on the hydration behaviour of lime.
\end{abstract}

\section{Introduction}

Limestone (mainly $\mathrm{CaCO}_{3}$ ) is one of the most widely occurring industrial minerals worldwide. It is not surprising that lime, obtained by calcining limestone, is a frequently used industrial base and features on the list of the top 50 industrial chemicals (National Lime Association, 1990). When applied as an alkali, unslaked lime, $\mathrm{CaO}$, is commonly converted to slaked lime, $\mathrm{Ca}(\mathrm{OH})_{2}$, by reacting it with water. The conversion of limestone to lime and its slaking with water, can be represented by the following reactions:

$$
\begin{aligned}
& \mathrm{CaCO}_{3}(\mathrm{~s}) \rightarrow \mathrm{CaO}(\mathrm{s})+\mathrm{CO}_{2}(\mathrm{~g}) \\
& \mathrm{CaO}(\mathrm{s})+\mathrm{H}_{2} \mathrm{O}(\mathrm{l}) \rightarrow \mathrm{Ca}(\mathrm{OH})_{2}(\mathrm{aq})
\end{aligned}
$$

Although it is the $\mathrm{Ca}(\mathrm{OH})_{2}$ species that is desired in the application, its production is closely linked to a number of physical and chemical influences. These include, among others, the origin of the limestone from which it is derived, calcining conditions in the kiln and constituents in the water used for slaking. Different geological origins of limestones can result in lime of different chemical compositions which can possibly influence its rate of hydration during the slaking process. Furthermore, calcining conditions inside the kiln can give hard burnt, medium burnt or soft burnt limes with different reactivities, i.e. different rates and extent of reaction with water (Gaylard, 1994). Chloride and sulphate ions are common constituents of many waters and are often found in high concentrations in water used for the slaking of lime.

Furthermore, conditions after production can also influence the reactivity and, consequently, the slaking rate of lime. Due to its hygroscopic nature, lime can be changed into $\mathrm{Ca}(\mathrm{OH})_{2}$ by any humidity present in the atmosphere, or revert back to $\mathrm{CaCO}_{3}$ due to the laws of thermodynamics which favour the more stable naturally occurring form (Strydom and Potgieter, 1997). Both back

\footnotetext{
* To whom all correspondence should be addressed.

I্]. (012) 420-2511; fax: (012) 362-5297; e-mail: cstrydom@postino.up.ac.za Received 23 March 2001; accepted in revised form 14 September 2001
}

conversions to either the slaked lime or limestone form can influence the rate of slaking of the lime. It is also known that this back conversion to limestone after atmospheric contact is influenced by the prevailing relative humidity (Meyer, 1998). This latter phenomenon can cause considerable operational problems at plant level to ensure the production of lime that complies with customer demands and expectations in terms of its reactivity.

The purpose of this investigation was to assess quantitatively the effect of various chemical influences (e.g. $\mathrm{SO}_{4}{ }^{2-}$ and $\mathrm{Cl}^{-}$ concentrations), whether it be from a geological origin or presence in the slaking water on the slaking rate of lime. Ultimately, the aim is to assist consumers in the correct choice of product and in using it optimally.

\section{Experimental procedure}

\section{Samples}

Samples from naturally occurring limestone deposits of different geological origin were collected from three sites in South Africa. Pienaars River limestone, just to the north of Pretoria, is a secondary limestone deposit occurring as calcrete nodules embedded in a silt/ clay matrix, while Beestekraal limestone, between the towns of Brits and Thabazimbi, is a primary deposit with a significant level of magnesium contamination. Lime Acres limestone is chemically the most pure limestone deposit in South Africa and the source of the bulk of unslaked lime sold in the country. The chemical composition of these three samples, as obtained by XRF analysis, is given in Table I. Using the values for the percentage of $\mathrm{CaO}$ in each sample, it was calculated that the maximum amount of $\mathrm{CaCO}_{3}$ in the Pienaars River sample is 75.6\% limestone, in the Beestekraal specimen $88.2 \%$ and in the Lime Acres material 98.7\%. These values were used to normalise the degrees of slaking obtained for each sample during the investigation. For purposes of comparison, a pure sample of $\mathrm{CaCO}_{3}$, obtained from Fluka, was also included in the investigation. 


\begin{tabular}{|c|c|c|c|}
\hline \multicolumn{4}{|c|}{$\begin{array}{c}\text { TABLE } 1 \\
\begin{array}{c}\text { Chemical composition of the various limestones } \\
\text { investigated }(\% \mathrm{~m} / \mathrm{m})\end{array}\end{array}$} \\
\hline $\begin{array}{l}\text { Element } \\
\text { expressed } \\
\text { as relevant } \\
\text { oxide (\%) }\end{array}$ & $\begin{array}{l}\text { Pienaars } \\
\text { River } \\
\text { Limestone }\end{array}$ & $\begin{array}{c}\text { Lime } \\
\text { Acres } \\
\text { Limestone }\end{array}$ & $\begin{array}{l}\text { Beestekraal } \\
\text { Limestone }\end{array}$ \\
\hline $\mathrm{SiO}_{2}$ & 18.95 & 0.54 & 4.42 \\
\hline $\mathrm{Al}_{2} \mathrm{O}_{3}$ & 2.40 & 0.26 & 0.80 \\
\hline $\mathrm{Fe}_{2} \mathrm{O}_{3}$ & 1.12 & 0.05 & 0.28 \\
\hline $\mathrm{MnO}$ & 0.08 & 0.54 & 0.86 \\
\hline $\mathrm{TiO}_{2}$ & 0.13 & 0.01 & 0.02 \\
\hline $\mathrm{CaO}$ & 42.37 & 55.34 & 49.47 \\
\hline $\mathrm{MgO}$ & 1.23 & 0.80 & 3.30 \\
\hline $\mathrm{P}_{2} \mathrm{O}_{5}$ & $<0.01$ & $<0.01$ & $<0.01$ \\
\hline $\mathrm{K}_{2}^{2} \mathrm{O}$ & 0.30 & 0.04 & 0.40 \\
\hline $\mathrm{Na}_{2} \mathrm{O}$ & 0.17 & 0.14 & 0.05 \\
\hline LOI & 34.09 & 42.99 & 40.93 \\
\hline Total & 100.84 & 100.71 & 100.53 \\
\hline
\end{tabular}

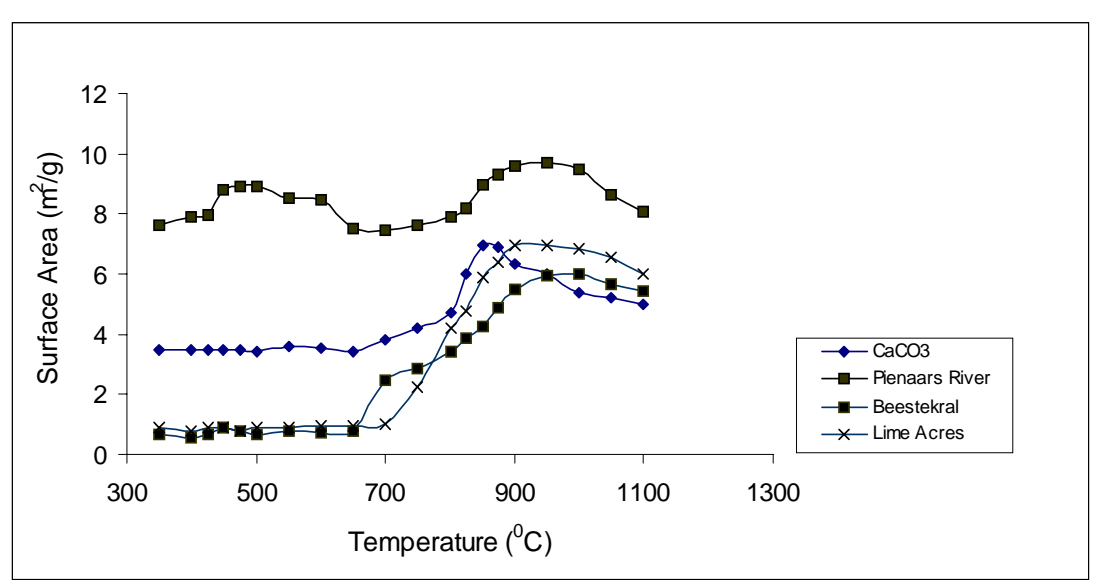

Figure 1

Surface area measurements of lime samples over a selected temperature range

\section{Surface area measurements}

Samples of $0.5 \mathrm{~g}$ of each material were heated for $30 \mathrm{~min}$ at temperatures ranging between $350^{\circ} \mathrm{C}$ to $1050^{\circ} \mathrm{C}$, cooled to room temperature in a desiccator and their surface areas measured. Measurements were performed with a BET Micrometrics Flowsorb II 2300 instrument, using the adsorption of nitrogen gas as an indication of the surface area. Surface area is one of the important properties of lime influencing its slaking rate and it depends heavily on calcining conditions in the kiln. The results obtained for the different materials are shown graphically in Fig. 1.

\section{Slaking rate measurements}

The various calcium carbonate-containing samples were each heated at $900^{\circ} \mathrm{C}$ for $5 \mathrm{~h}$, cooled in a desiccator, and $3 \mathrm{~g}$ of each sample was then added to $250 \mathrm{~m} \ell$ of distilled water in a clean plastic bottle. The bottle with its contents was shaken on a platform shaker for fixed time intervals before being removed and filtered immediately. After filtration the residue was dried at $120^{\circ} \mathrm{C}$ for $1 \mathrm{~h}$ to remove any adsorbed water. The percentage slaking was calculated by determining the amount of $\mathrm{Ca}(\mathrm{OH})_{2}$ formed. This was accomplished by weighing out approximately $1.000 \mathrm{~g}$ of the dried samples and heating it at $550^{\circ} \mathrm{C}$ for $1 \mathrm{~h}$ before determining the mass loss. The mass losses obtained were normalised to the total amount of limestone originally present in the various samples to account for possible effects of impurities and differences in chemical compositions between the materials investigated.

The distilled water was then replaced by solutions of $1 \mathrm{~mol} / \mathrm{dm}^{3}$ $\mathrm{NaCl}$ and $1 \mathrm{~mol} / \mathrm{dm}^{3} \mathrm{Na}_{2} \mathrm{SO}_{4}$ respectively, and the process was repeated to investigate the influence of these ions on the slaking of the different lime samples. The values obtained in each case are shown in Tables 2 to 5 .

\section{Results and discussion}

From the curves shown in Fig. 1, it can be concluded that the three natural limestones all produce, within experimental errors, limes with similar surface areas at temperatures of approximately $900^{\circ} \mathrm{C}$. However, these limes all have much lower surface areas at the various heating temperatures than the chemically pure sample. From this it can be deduced that all three limes produced from different natural limestones should display similar hydration rates during slaking, except if their chemical compositions have an influence in this regard. The decrease in surface areas for all the samples above a temperature of $900^{\circ} \mathrm{C}$ corresponds to previous observations reported in the literature and is probably due to the sintering of $\mathrm{CaO}$ crystals to form enlarged crystallites (Murray et al., 1954).

The data summarised in Tables II to V indicate that the addition of the $\mathrm{NaCl}$ to the various limes slightly retards the hydration process in each case, regardless of the origin of the lime. This is a rather surprising result, as it would be expected that the formation of $\mathrm{CaCl}_{2}$, which is much more soluble than $\mathrm{Ca}(\mathrm{OH})_{2}$, would accelerate the slaking rate of the lime. It can probably be explained if one assumes that small amounts of $\mathrm{CaCl}_{2} \cdot \mathrm{H}_{2} \mathrm{O}, \mathrm{CaCl}_{2} \cdot 2 \mathrm{H}_{2} \mathrm{O}$ and/or $\mathrm{CaCl}_{2} \cdot 6 \mathrm{H}_{2} \mathrm{O}$ have also formed in the course of the reaction and contributed to the total mass loss observed at $550^{\circ} \mathrm{C}$. This requires more detailed investigation with a TGA/DTA apparatus to separate the contributions of the relevant compounds to the total mass loss.

A similar trend is evident upon using $\mathrm{Na}_{2} \mathrm{SO}_{4}$ instead of pure water. However, in this case, the decreases in the hydration rates of all the different limes are significantly more pronounced than in the case of the chloride solution. One can explain this observation by noting that the reaction product in this instance, namely $\mathrm{CaSO}_{4} \cdot \mathrm{xH}_{2} \mathrm{O}$, is a fairly insoluble compound. This means that water required for the hydration of the $\mathrm{CaO}$ particle encapsulated in a skin of calcium sulphate, first has to diffuse through this layer. In this case, drying at $120^{\circ} \mathrm{C}$ before subjecting the sample to heating at $550{ }^{\circ} \mathrm{C}$ to determine the mass loss, would have gotten rid of most of the water that any calcium sulphate present in the sample of $\mathrm{Ca}(\mathrm{OH})_{2}$ could contribute. Therefore, a true picture of the nature of the effect of sulphate ions on the hydration rate is obtained, although its real magnitude requires refining through more detailed TGA measurements.

The curves shown in Fig. 2 indicate that the lime prepared from chemically pure calcium carbonate has the fastest rate of hydration and slakes to the largest degree. Pienaars River and Lime Acres 


\begin{tabular}{|c|c|c|c|c|}
\hline \multicolumn{5}{|c|}{$\begin{array}{l}\text { TABLE } 2 \\
\text { Percentage slaking of } \mathrm{CaO} \text { prepared from pure } \\
\mathrm{CaCO}_{3} \text { with water, } 1.0 \mathrm{M} \mathrm{NaCl} \text { and } 1.0 \mathrm{M} \mathrm{Na}_{2} \mathrm{SO}_{4}\end{array}$} \\
\hline $\mathrm{CaCO}_{3}$ & $\begin{array}{l}\text { Time } \\
(\min )\end{array}$ & $\begin{array}{c}\% \text { mass } \\
\text { loss at } \\
550^{\circ} \mathrm{C}\end{array}$ & $\begin{array}{c}\% \\
\text { slaking }\end{array}$ & $\begin{array}{c}\text { Normalised } \\
\% \text { slaking }\end{array}$ \\
\hline Water & $\begin{array}{c}2 \\
5 \\
10 \\
15\end{array}$ & $\begin{array}{l}22.96 \\
23.82 \\
24.10 \\
24.13\end{array}$ & $\begin{array}{l}94.5 \\
98.0 \\
99.2 \\
99.3\end{array}$ & $\begin{array}{l}94.5 \\
98.0 \\
99.2 \\
99.3\end{array}$ \\
\hline $1.0 \mathrm{M} \mathrm{NaCl}$ & $\begin{array}{c}2 \\
5 \\
10 \\
15\end{array}$ & $\begin{array}{l}22.09 \\
22.98 \\
23.28 \\
23.41\end{array}$ & $\begin{array}{l}90.9 \\
94.6 \\
95.8 \\
96.4\end{array}$ & $\begin{array}{l}90.9 \\
94.6 \\
95.8 \\
96.4\end{array}$ \\
\hline $1.0 \mathrm{M} \mathrm{Na}_{2} \mathrm{SO}_{4}$ & $\begin{array}{c}2 \\
5 \\
10 \\
15\end{array}$ & $\begin{array}{l}13.97 \\
15.72 \\
16.02 \\
16.00\end{array}$ & $\begin{array}{l}57.5 \\
64.7 \\
65.9 \\
65.8\end{array}$ & $\begin{array}{l}57.5 \\
64.7 \\
65.9 \\
65.8\end{array}$ \\
\hline
\end{tabular}

\begin{tabular}{|c|c|c|c|c|}
\hline \multicolumn{5}{|c|}{ 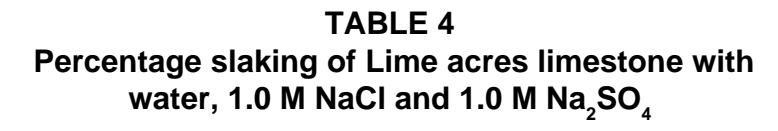 } \\
\hline $\mathrm{CaCO}_{3}$ & $\begin{array}{l}\text { Time } \\
(\mathrm{min})\end{array}$ & $\begin{array}{c}\% \text { mass } \\
\text { loss at } \\
550^{\circ} \mathrm{C}\end{array}$ & $\begin{array}{c}\% \\
\text { slaking }\end{array}$ & $\begin{array}{l}\text { Normalised } \\
\% \text { slaking }\end{array}$ \\
\hline Water & $\begin{array}{c}2 \\
5 \\
10 \\
15\end{array}$ & $\begin{array}{l}20.69 \\
22.99 \\
23.37 \\
23.46\end{array}$ & $\begin{array}{l}85.1 \\
94.6 \\
96.2 \\
96.5\end{array}$ & $\begin{array}{l}86.2 \\
95.6 \\
97.5 \\
97.8\end{array}$ \\
\hline $1.0 \mathrm{M} \mathrm{NaCl}$ & $\begin{array}{c}2 \\
5 \\
10 \\
15\end{array}$ & $\begin{array}{l}19.92 \\
22.57 \\
22.93 \\
22.92\end{array}$ & $\begin{array}{l}82.0 \\
92.9 \\
94.4 \\
94.3\end{array}$ & $\begin{array}{l}83.1 \\
94.1 \\
95.6 \\
95.6\end{array}$ \\
\hline $1.0 \mathrm{M} \mathrm{Na}_{2} \mathrm{SO}_{4}$ & $\begin{array}{c}2 \\
5 \\
10 \\
15\end{array}$ & $\begin{array}{l}15.13 \\
15.61 \\
16.03 \\
16.06\end{array}$ & $\begin{array}{l}62.3 \\
64.3 \\
66.0 \\
66.1\end{array}$ & $\begin{array}{l}63.1 \\
65.1 \\
66.8 \\
67.0\end{array}$ \\
\hline
\end{tabular}

TABLE 3

Percentage slaking of Pienaars River limestone with water, $1.0 \mathrm{M} \mathrm{NaCl}$ and $1.0 \mathrm{M} \mathrm{Na}_{2} \mathrm{SO}_{4}$

\begin{tabular}{|l|c|c|c|c|}
\hline $\mathbf{C a C O}_{3}$ & $\begin{array}{c}\text { Time } \\
\text { (min) }\end{array}$ & $\begin{array}{c}\text { \% mass } \\
\text { loss at } \\
\mathbf{5 5 0 ^ { \circ } \mathbf { C }}\end{array}$ & $\begin{array}{c}\text { \% } \\
\text { slaking }\end{array}$ & $\begin{array}{c}\text { Normalised } \\
\text { \% slaking }\end{array}$ \\
\hline Water & 2 & 16.92 & 69.6 & 92.1 \\
& 5 & 17.75 & 73.1 & 96.6 \\
& 10 & 18.10 & 74.5 & 98.5 \\
& 15 & 18.01 & 74.1 & 98.0 \\
\hline $1.0 \mathrm{M} \mathrm{NaCl}$ & 2 & 16.42 & 65.6 & 89.4 \\
& 5 & 16.55 & 68.1 & 90.1 \\
& 10 & 16.98 & 70.0 & 92.4 \\
& 15 & 17.16 & 70.7 & 93.5 \\
\hline $1.0 \mathrm{M} \mathrm{Na}_{2} \mathrm{SO}_{4}$ & 2 & 10.17 & 41.9 & 55.4 \\
& 5 & 13.70 & 56.4 & 74.5 \\
& 10 & 14.15 & 58.3 & 77.1 \\
& 15 & 14.22 & 58.5 & 77.4 \\
\hline
\end{tabular}

\begin{tabular}{|c|c|c|c|c|}
\hline \multicolumn{5}{|c|}{$\begin{array}{c}\text { TABLE } 5 \\
\text { Percentage slaking of Beestekraal limestone with } \\
\text { water, } 1.0 \mathrm{M} \mathrm{NaCl} \text { and } 1.0 \mathrm{M} \mathrm{Na}_{2} \mathrm{SO}_{4}\end{array}$} \\
\hline $\mathrm{CaCO}_{3}$ & $\begin{array}{l}\text { Time } \\
\text { (min) }\end{array}$ & $\begin{array}{l}\% \text { mass } \\
\text { loss at } \\
550^{\circ} \mathrm{C}\end{array}$ & $\begin{array}{c}\% \\
\text { slaking }\end{array}$ & $\begin{array}{l}\text { Normalised } \\
\% \text { slaking }\end{array}$ \\
\hline Water & $\begin{array}{c}2 \\
5 \\
10 \\
15\end{array}$ & $\begin{array}{l}18.69 \\
19.58 \\
20.02 \\
20.1\end{array}$ & $\begin{array}{l}76.9 \\
80.6 \\
82.4 \\
82.7\end{array}$ & $\begin{array}{l}87.2 \\
91.4 \\
93.4 \\
93.8\end{array}$ \\
\hline $1.0 \mathrm{M} \mathrm{NaCl}$ & $\begin{array}{c}2 \\
5 \\
10 \\
15\end{array}$ & $\begin{array}{l}18.25 \\
18.50 \\
18.99 \\
19.04\end{array}$ & $\begin{array}{l}75.1 \\
76.1 \\
78.1 \\
78.3\end{array}$ & $\begin{array}{l}85.2 \\
86.3 \\
88.6 \\
88.8\end{array}$ \\
\hline $1.0 \mathrm{M} \mathrm{Na}_{2} \mathrm{SO}_{4}$ & $\begin{array}{c}2 \\
5 \\
10 \\
15\end{array}$ & $\begin{array}{l}13.15 \\
14.14 \\
15.20 \\
15.18\end{array}$ & $\begin{array}{l}54.1 \\
58.2 \\
62.6 \\
62.5\end{array}$ & $\begin{array}{l}61.3 \\
66.0 \\
70.9 \\
70.8\end{array}$ \\
\hline
\end{tabular}

limestones display similar hydration behaviour. The major difference in their chemical compositions is their silica contents, and this does not seem to influence the slaking rate. Beestekraal lime has a noticeably lower rate of hydration than the other limes. Its most significant difference in terms of chemical composition is in the amount of $\mathrm{MgO}$ that it possesses. One can deduce that $\mathrm{MgO}$ content definitely influences slaking behaviour of limes. This is in agreement with well-documented evidence (Taylor, 1997) that $\mathrm{MgO}$ hydrates slower than $\mathrm{CaO}$.

Once a significant amount of chloride is added to the solution, the hydration behaviour of the different

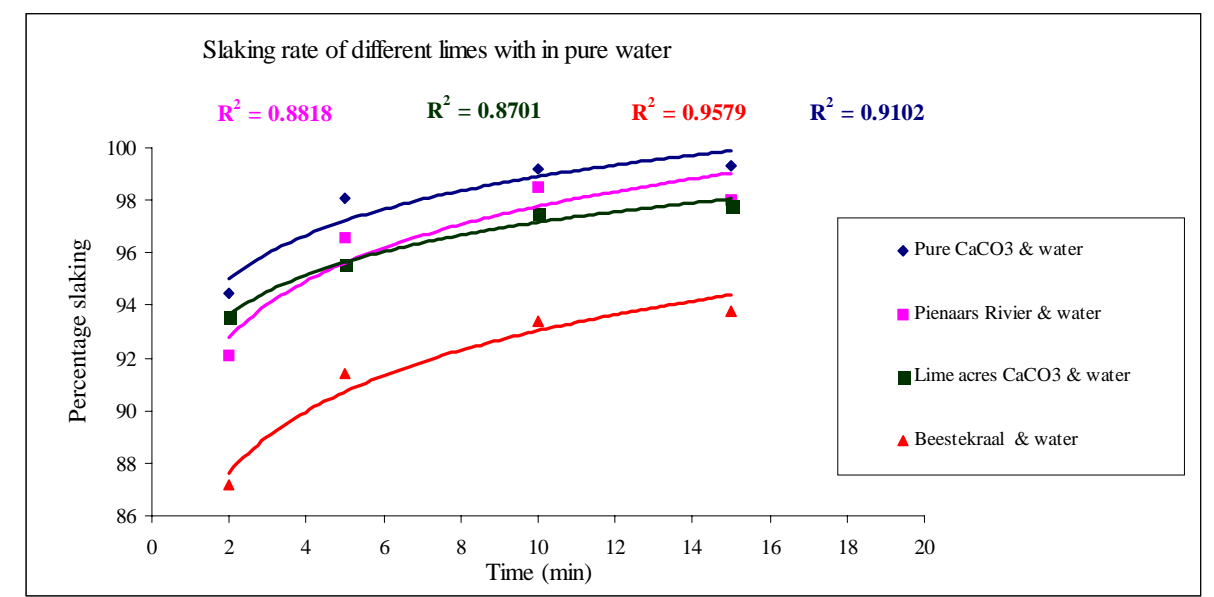

Figure 2

Slaking rate of the various lime samples in pure water 
limes is more clearly differentiated, as can be seen in Fig. 2. Beestekraal lime again hydrates the slowest, but there is now also a noticeable difference in the slaking rate between Pienaars River and Lime Acres lime. Lime Acres lime slakes faster than the Pienaars River material and displays a similar hydration rate than the chemically pure lime. This difference in hydration behaviour between Lime Acres lime and Pienaars River lime in the chloride solution requires additional investigation to determine its cause.

In the sulphate medium, a reversal of the hydration behaviour of most of the limes, with the exception of the Pienaars River material, was observed. This is schematically depicted by the curves in Fig. 4. The chemically pure lime and the Lime Acres lime now slake slower and to a lesser extent than the Beestekraal material. This can be explained if one assumes that their general higher reactivity leads to a faster formation and thicker "skin" of calcium sulphate around each individual calcium oxide particle than is the case with the Beestekraal sample, resulting in a lower slaking rate. The reason why the Pienaars River sample does not conform to its behaviour pattern observed so far, can possibly be ascribed to its very much higher silica content. This difference in chemical composition compared to the other two limes produced from naturally-occurring limestones would render it less susceptible to the formation of calcium sulphate and the formation of a "skin"'"around the individual lime particles. Therefore, it is not so prone to a retardation of slaking and displays the fastest hydration rate and extent of hydration of all the materials investigated. A logarithmic rate law to describe the slaking process reasonably well was found to be generally valid.

\section{Conclusions}

The following conclusions can be drawn from this investigation:

- Similar calcining conditions lead to limes with similar surface areas and theoretically similar reactivities.

- Differences in the chemical compositions of the limestones definitely have effects on their rates of hydration.

- Hydration rate effects of the different limestones due to their differences in chemical composition depend on the specific type of medium in which the effect manifests itself.

- All limes investigated slaked faster in pure water than in solutions containing sulphate ions. This same phenomenon is observed in the solution containing chloride ions.

- In all the cases investigated, the slaking rates could be reasonably well described by a logarithmic rate law, regardless of whether the hydration process was retarded or not.

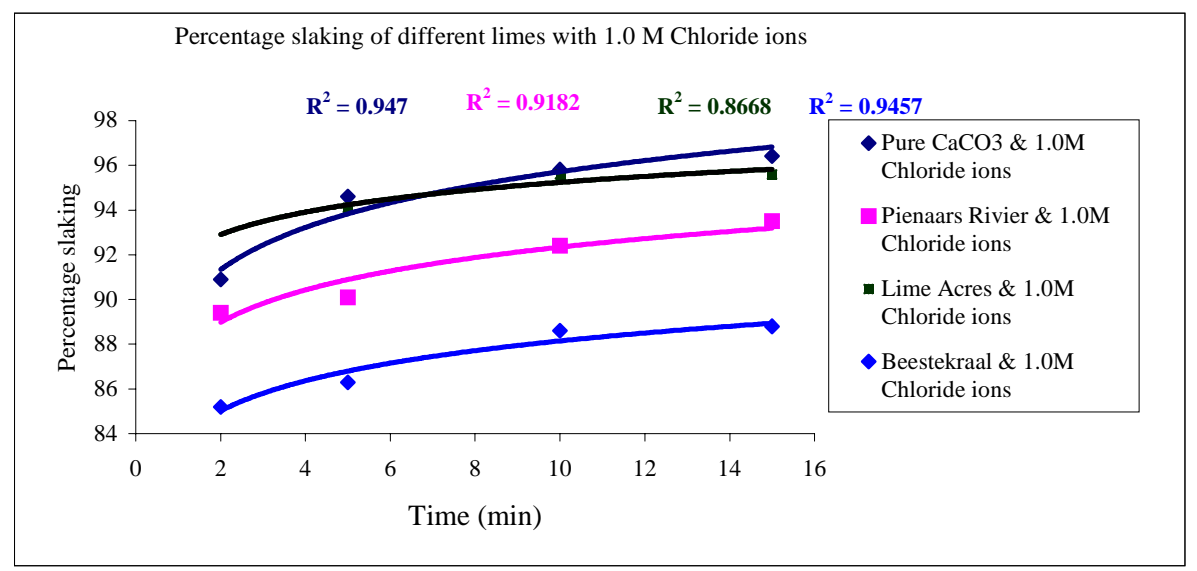

Figure 3

Slaking rate of the various lime samples in water containing $1 \mathrm{M} \mathrm{NaCl}$

Percentage slaking of different limes with $1.0 \mathrm{M} \mathrm{Na}_{2} \mathrm{SO}_{4}$

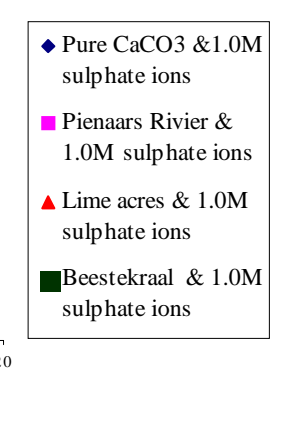

Figure 4

samples in water containing $1 \mathrm{M} \mathrm{Na}_{2} \mathrm{SO}_{4}$

\section{Acknowledgements}

Pretoria Portland Cement Co. Ltd (PPC) is gratefully acknowledged for the supply of the materials used in this investigation. The authors also want to thank the NRF (National Research Foundation), University of Pretoria and Technikon Pretoria for financial assistance.

\section{References}

GAYLARD JM (1994) PPC (Pretoria Portland Cement Co. Ltd.) Inhouse Cement Technology Course, Lecture notes on Lime Kilns.

MEYER H (1998) Personal communication. General Manager, PPC Lime Acres factory.

MURRAY JA, FISCHER HC and ROLNICK LS (1954) Shrinkage of high-calcium limestones during burning. J. Am. Ceram. Soc. 37 (7) 323-328.

NATIONAL LIME ASSOCIATION (NLA) (1990) Lime: Handling, Application and Storage - Bulletin 213. NLA, Arlington, USA.

STRYDOM CA and POTGIETER JH (1997) An investigation into the chemical nature of the reactivity of lime. Proc. of the $10^{\text {th }}$ Int. Congr. of the Chem. Cem., Gothenburg, Sweden. 2 ii049.

TAYLOR HFW (1997) Cement Chemistry. Thomas Telford Publishers, London, UK. 459 pp. 